[Chem. Pharm. Bull.

$34(7) 2780-2785(1986)]$

\title{
Steroidal Inhibitors of Microbial Degradation of Sterol Side Chains
}

\author{
Mikio Ohtsuka, Yoshinori Fujimoto, and Nobuo IkeKawa* \\ Department of Chemistry, Tokyo Institute of Technology, \\ O-okayama, Meguro-ku, Tokyo 152, Japan
}

(Received January 7, 1986)

\begin{abstract}
Methyl esters of acetylene carboxylic acids ( 2 and 3), an $\alpha$-bromo acid (4), and $\alpha, \alpha$-difluoro acids (5 and 6) were synthesized as analogues of the C-24 carboxylic acid which is an intermediate in the microbial degradation of sterol side chains, and these compounds were shown to be inhibitors of the degradation reaction.

Keywords__-inhibitor; microbial degradation; sterol side chain; acetylene carboxylic acid methyl ester; bromo acid methyl ester; difluoro acid methyl ester; cholesterol; sitosterol; cholenic acid; Mycobacterium sp.
\end{abstract}

The microbial degradation of the side chains of cholesterol, sitosterol, and campesterol has been reported to proceed through the C-26, C-24, and C-22 carboxylic acids, as shown in Chart 1. ${ }^{1)}$ Almost 20 years ago, a number of substances were tested by Arima and other researchers for ability to block the complete degradation of these sterols, and this work resulted in the successful microbial production of 17 -keto steroids. ${ }^{2)}$ In an attempt to regulate this multi-step enzymatic reaction at earlier stages, in particular the stage involving the C-24

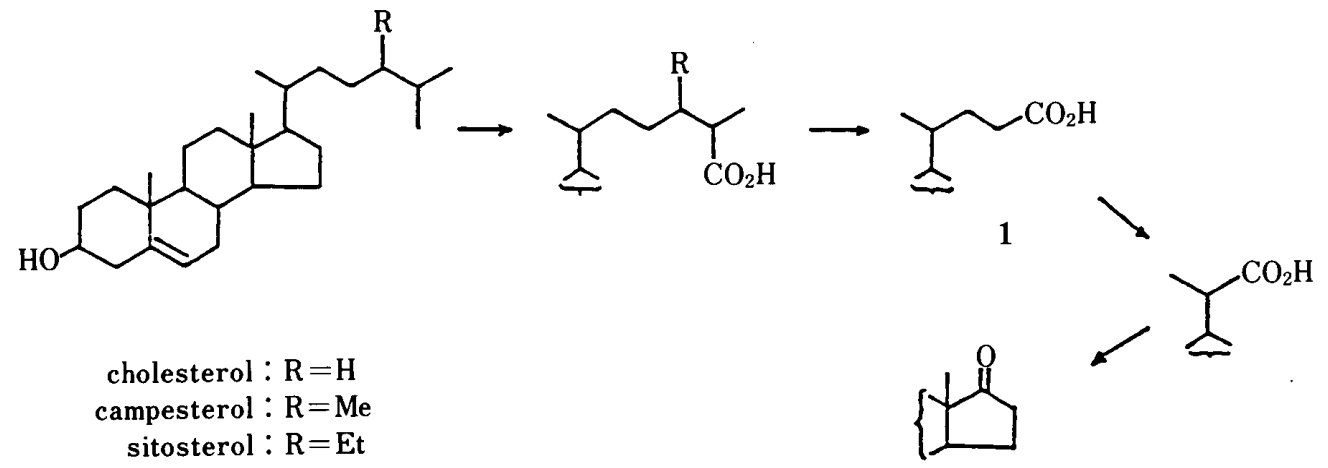

Chart 1

carboxylic acid (1), we have prepared several steroidal compounds (2-6) as analogues of the C-24 acid, and investigated their inhibitory effects on the microbial degradation of sterol side chains. The C-24 acid, which we hoped would be accumulated, is a useful compound, since a C-24 carboxylic acid (cholenic acid) has been utilized as a starting material for the synthesis of vitamin $\mathrm{D}_{3}$ metabolites and their analogues. ${ }^{3)}$

Treatment of the known dibromide $7^{4)}$ with $n$-BuLi $(2.5 \mathrm{eq})$ and then with dry ice afforded the C-24 acetylene acid 8 in $64 \%$ yield. Acidic treatment ( $p$-TsOH in refluxing aq. dioxane) of 8 afforded the $3 \beta$-alcohol 9 in $77 \%$ yield. This was esterified with diazomethane to give the methyl ester 2 . The enone 10 was also prepared by a modified Oppenauer oxidation ${ }^{5)}$ of 2 . The synthesis of the C-25 acetylene acid 3 was carried out by a slight modification of the 
<smiles>C=CC(C)C(C)(C)C#CC(=O)O</smiles>

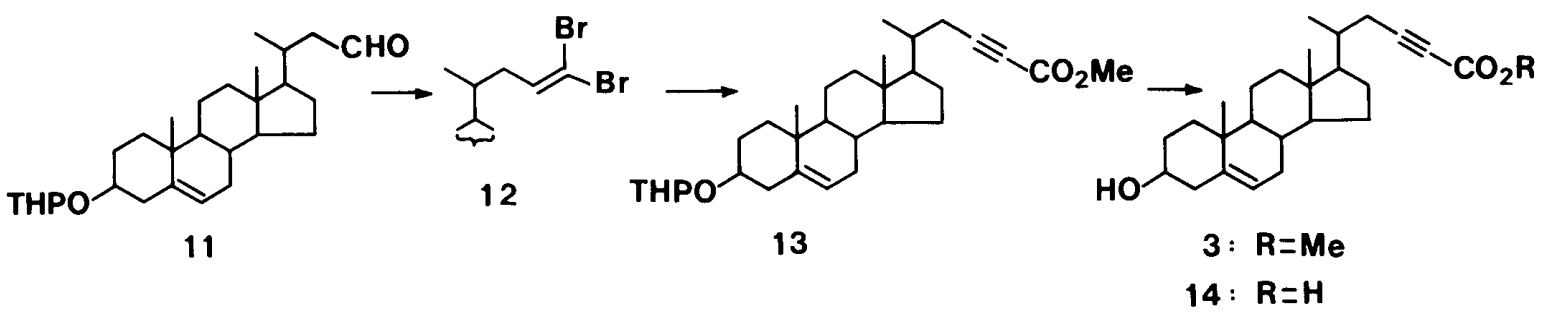

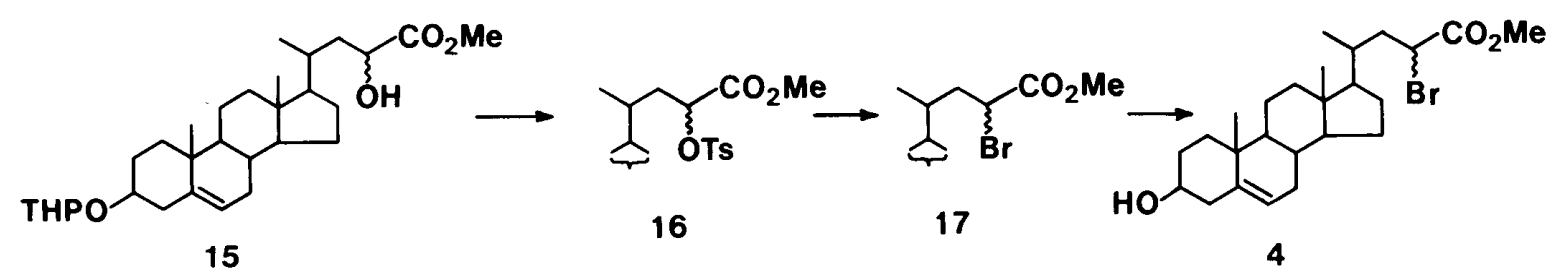

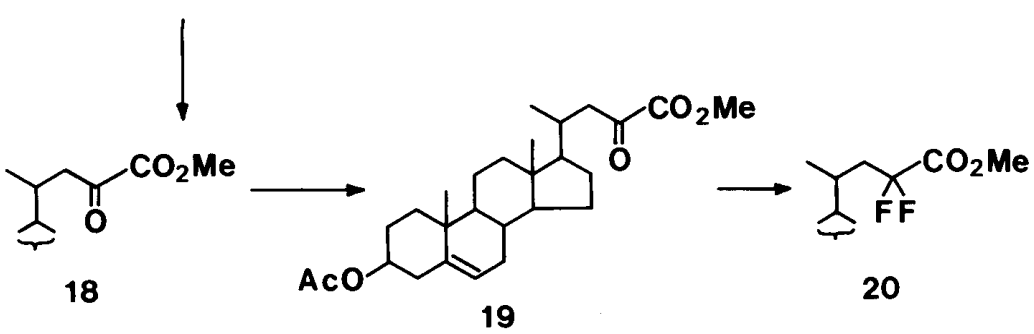

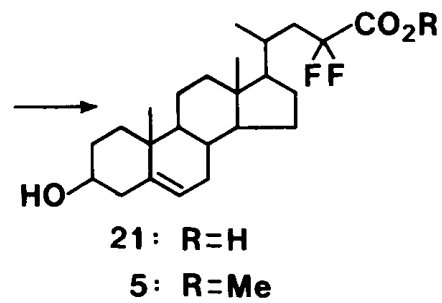<smiles>COC(=O)CC(F)(F)CCC(C)C1CCC2C1CCC13CCC(OC(C)=O)CC1=CCC2C3C</smiles>

22<smiles>COC(=O)CCC(C)C1CCC2C1CCC1C2CC=C2CC(O)CCC21C</smiles>

6

Chart 2

above method. The starting dibromide 12 , obtained from the $\mathrm{C}-23$ aldehyde $11^{6)}$ according to the known method $\left(\mathrm{CBr}_{4}-\mathrm{Ph}_{3} \mathrm{P}, 79 \%\right.$ yield $),{ }^{7)}$ was converted into the methyl ester 13 using chloromethyl formate instead of dry ice, in $77 \%$ yield. Acidic treatment of the tetrahydropyranyl (THP) ether 13 afforded the $3 \beta$-alcohol 3 in $88 \%$ yield. Hydrolysis of 3 with base gave the acetylene acid 14 in $84 \%$ yield.

At this stage, a preliminary biological test showed that the methyl esters 2 and 3 , but not the acids 9 and 14, inhibited sterol side chain degradation. Thus, the following compounds were prepared in the form of methyl esters. 
TABLE I. Inhibitory Effect of Compounds $2-6$ on Cholesterol Side Chain Degradation

\begin{tabular}{|c|c|c|c|c|c|}
\hline Compound & $\begin{array}{c}\text { Added weight } \\
\text { (mg) }\end{array}$ & $\begin{array}{c}\text { Conversion into } \mathrm{AD}^{a)} \\
(\%)\end{array}$ & Compound & $\begin{array}{l}\text { Added weight } \\
\text { (mg) }\end{array}$ & $\begin{array}{c}\text { Conversion into } \mathrm{AD}^{a)} \\
(\%)\end{array}$ \\
\hline Not added & - & 51 & 4 & 0.8 & 36 \\
\hline \multirow[t]{3}{*}{2} & 0.8 & 45 & & 2.0 & 20 \\
\hline & 2.0 & 15 & & 5.0 & 16 \\
\hline & 5.0 & 7 & 5 & 0.8 & 41 \\
\hline \multirow[t]{3}{*}{10} & 0.8 & 50 & & 2.0 & 11 \\
\hline & 2.0 & 13 & & 5.0 & 1 \\
\hline & 5.0 & 6 & 6 & 0.8 & 44 \\
\hline \multirow[t]{3}{*}{3} & 0.8 & 57 & & 2.0 & 20 \\
\hline & 2.0 & 33 & & 5.0 & 6 \\
\hline & 5.0 & 35 & & & \\
\hline
\end{tabular}

a) Androst-4-ene-3,17-dione.

The synthesis of the bromo ester 4 was started with the hydroxy ester 15 (epimeric mixture at the C-23 position), which was obtained by hydroxylation ${ }^{8)}$ (lithium diisopropylamide, $\mathrm{O}_{2}$ ) of $3 \beta$-tetrahydropyranyloxycholenic acid methyl ester. Treatment of the corresponding tosylate 16 with $\mathrm{LiBr}$ afforded the bromide 17 in $89 \%$ yield. Deprotection of the THP ether of 17 gave the bromo ester 4 in $89 \%$ yield.

Swern oxidation of $\mathbf{1 5}$ gave in $95 \%$ yield the keto ester 18, which was converted into the acetate 19 in $59 \%$ yield upon treatment with $\mathrm{HCl}$ in methanol followed by acetylation (acetyl chloride-pyridine). Treatment of 19 with diethylaminosulfur trifluoride (DAST) in $\mathrm{CH}_{2} \mathrm{Cl}_{2}$ gave the $\alpha$, $\alpha$-difluoro ester 20 in $67 \%$ yield. Hydrolysis $(\mathrm{KOH} / \mathrm{methanol})$ of 20 smoothly afforded the hydroxy acid 21 in $95 \%$ yield. Diazomethane treatment of 21 furnished the methyl ester 5 quantitatively. The homologous difluoro ester 6 was obtained from the acetate $22^{9)}$ in the same manner.

With the possible inhibitors in hand, their effect on the sterol side chain degradation was examined. The microorganism used was Mycobacterium sp. NRRL B-3805, ${ }^{10)}$ which is known to produce androst-4-ene-3,17-dione (AD), and cholesterol was incubated with this organism in the presence of compounds $2-6$ and the enone 10. The results are listed in Table I. Among the compounds tested, the difluoro ester 5 exhibited the strongest inhibitory action; cholesterol degradation was completely blocked and cholesterol was recovered unchanged at the dose level of $5 \mathrm{mg}$. The carbon length of the side chain appeared to be of importance for activity since the C-24 acetylene ester 2 and the C-24 difluoro ester 5 were more potent than the respective $\mathrm{C}-25$ homologues 3 and 6 . Both 3-hydroxy-5-ene and 4-en-3-one functionalities in the steroid nucleus were found to be equally effective, since the acetylene ester 2 and the corresponding enone 10 exhibited comparable levels of inhibition. When commercial sitosterol was incubated in the presence of these inhibitors, the difluoro ester 5 also showed the strongest inhibition activity. In order to confirm that the observed inhibitory effect is related to the structural features of the test compounds, some steroids such as cholestane and $3 \beta$-hydroxychol-5-ene were also investigated. ${ }^{11)}$ These compounds proved to be practically inactive.

Although we have not succeeded in accumulating any intermediates as yet, further studies including in vitro experiments are under way to define the enzymatic step(s) blocked by these inhibitors. 
nuclear magnetic resonance $\left({ }^{1} \mathrm{H}-\mathrm{NMR}\right)$ spectra were recorded on a Hitachi R-24A (60 MHz) (unless otherwise noted), JEOL JNH-PS-100 (100 MHz), or JEOL FX-200 $(200 \mathrm{MHz})$ spectrometer in $\mathrm{CDCl}_{3}$ solution with tetramethylsilane (TMS) as an internal reference. Ultraviolet (UV) spectra were measured on a Shimadzu UV-200 spectrometer in a solution of ethanol. Mass spectra (MS) $(70 \mathrm{eV})$ were obtained with a Shimadzu GC-MS 9020 DF spectrometer operating in a GC-MS mode except for compounds 8, 9, 13, 14 and 21, which were recorded in a direct inlet system. Column chromatography was performed with Kieselgel 60 (70-230 mesh, E. Merck). Gas liquide chromatography (GLC) was performed on a Shimadzu GC-7A instrument equipped with a $1 \mathrm{~m} \times 3 \mathrm{~mm}$ i.d. glass column containing $1 \% \mathrm{OV}-17$ on Shimalite W, operating at $260^{\circ} \mathrm{C}$. The usual work-up refers to dilution with sat. aq. $\mathrm{NH}_{4} \mathrm{Cl}$, extraction with the organic solvent indicated in parenthesis, washing to neutrality, drying, filtration and evaporation under a vacuum. THF refers to tetrahydrofuran.

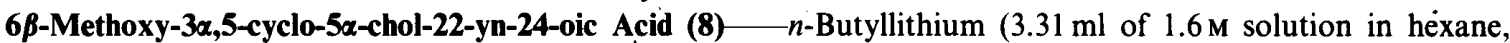
$5.3 \mathrm{mmol})$ was added to a solution of the dibromide $7(1.09 \mathrm{~g}, 2.21 \mathrm{mmol})$ in THF $(15 \mathrm{ml})$ at $-78^{\circ} \mathrm{C}$, and the mixture was stirred for $30 \mathrm{~min}$. Then, dry ice $(1 \mathrm{~g})$ was added at $-78^{\circ} \mathrm{C}$ and the reaction mixture was warmed to room temperature over $1 \mathrm{~h}$. After the usual work-up (ethyl acetate), the crude product was purified by silica gel column chromatography. Elution with hexane-ethyl acetate $(3: 1)$ gave $543 \mathrm{mg}(1.41 \mathrm{mmol}, 64 \%)$ of the carboxylic acid 8 as an oil. ${ }^{1} \mathrm{H}-\mathrm{NMR} \delta: 0.73\left(3 \mathrm{H}, \mathrm{s}, 18-\mathrm{CH}_{3}\right), 1.01\left(3 \mathrm{H}, \mathrm{s}, 19-\mathrm{CH}_{3}\right), 1.25\left(3 \mathrm{H}, \mathrm{d}, J=7.2 \mathrm{~Hz}, 21-\mathrm{CH}_{3}\right), 2.79(1 \mathrm{H}, \mathrm{m}, 6-\mathrm{H})$, $3.32\left(3 \mathrm{H}, \mathrm{s}, 6-\mathrm{OCH}_{3}\right), 8.40(1 \mathrm{H}$, br s, $\mathrm{COOH}) . \mathrm{MS} m / z: 384\left(\mathrm{M}^{+}\right), 340\left(\mathrm{M}-\mathrm{CO}_{2}\right)$.

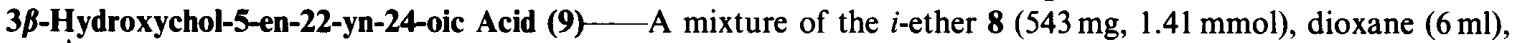
$\mathrm{H}_{2} \mathrm{O}(2 \mathrm{ml}$ ) and a catalytic amount of $p$-toluenesulfonic acid was refluxed for $2 \mathrm{~h}$. The usual work-up (ethyl acetate) afforded a crude product, which was crystallized from methanol to give the carboxylic acid $9(403 \mathrm{mg}, 77 \%), \mathrm{mp}$ $213.5-215^{\circ} \mathrm{C}$. UV $\lambda_{\max }^{\mathrm{EtOH}} \mathrm{nm}(\log \varepsilon): 218.5$ (3.3). $\mathrm{MS} m / z: 326\left(\mathrm{M}-\mathrm{CO}_{2}\right)$.

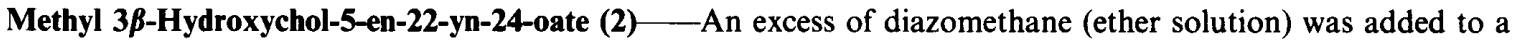
suspension of the carboxylic acid $9(205 \mathrm{mg})$ in ether at $0{ }^{\circ} \mathrm{C}$, and the mixture was stirred for $10 \mathrm{~min}$. The solvent was evaporated off and the residue was chromatographed on silica gel. Elution with hexane-ethyl acetate $(4: 1)$ gave the methyl ester $2(202 \mathrm{mg}, 0.53 \mathrm{mmol}, 95 \%), \mathrm{mp} 167-169^{\circ} \mathrm{C}$ (from ethyl acetate). ${ }^{1} \mathrm{H}-\mathrm{NMR}(100 \mathrm{MHz}) \delta: 0.76(3 \mathrm{H}, \mathrm{s}$, $\left.18-\mathrm{CH}_{3}\right), 1.05\left(3 \mathrm{H}, \mathrm{s}, 19-\mathrm{CH}_{3}\right), 1.31\left(3 \mathrm{H}, \mathrm{d}, J=6 \mathrm{~Hz}, 21-\mathrm{CH}_{3}\right), 3.60(1 \mathrm{H}, \mathrm{m}, 3-\mathrm{H}), 3.76\left(3 \mathrm{H}, \mathrm{s}, \mathrm{CO}_{2} \mathrm{CH}_{3}\right), 5.36(1 \mathrm{H}, \mathrm{m}$, 6-H). MS $m / z: 384\left(\mathrm{M}^{+}\right)$.

Methyl 3-Oxochol-4-en-22-yn-24-0ate (10)_-A solution of the alcohol 2 (100 mg, $0.26 \mathrm{mmol})$ and 1-methyl-4piperidone $^{5)}(0.32 \mathrm{ml}, 2.6 \mathrm{mmol})$ in toluene $(10 \mathrm{ml})$ was refluxed under a Dean-Stark trap until ca. $2 \mathrm{ml}$ of distillate had been collected. Aluminum isopropoxide $(80 \mathrm{mg}, 0.39 \mathrm{mmol})$ was added to the solution, and the mixture was refluxed for $6 \mathrm{~h}$. The usual work-up (ethyl acetate) gave a'crude product, which was chromatographed on silica gel. Elution with hexane-ethyl acetate $(4: 1)$ gave the enone $10(72 \mathrm{mg}, 0.19 \mathrm{mmol}, 73 \%)$ as an amorphous solid. ${ }^{1} \mathrm{H}-\mathrm{NMR} \delta: 0.75$ $\left(3 \mathrm{H}, \mathrm{s}, 18-\mathrm{CH}_{3}\right), 1.03\left(3 \mathrm{H}, \mathrm{s}, 19-\mathrm{CH}_{3}\right), 1.30\left(3 \mathrm{H}, \mathrm{d}, J=6 \mathrm{~Hz}, 21-\mathrm{CH}_{3}\right), 3.75\left(3 \mathrm{H}, \mathrm{s}, \mathrm{CO}_{2} \mathrm{CH}_{3}\right), 5.63(1 \mathrm{H}, \mathrm{s}, 4-\mathrm{H}) . \mathrm{MS}$ $m / z: 382\left(\mathrm{M}^{+}\right)$.

24,24-Dibromo-3 $\beta$-tetrahydropyranyloxychola-5,23-diene (12)-A mixture of triphenylphosphine $(4.24 \mathrm{~g}$, $16.2 \mathrm{mmol})$ and carbon tetrabromide $(2.68 \mathrm{~g}, 8.09 \mathrm{mmol})$ in $\mathrm{CH}_{2} \mathrm{Cl}_{2}(10 \mathrm{ml})$ was stirred at $0^{\circ} \mathrm{C}$ for $40 \mathrm{~min}$. A solution of the aldehyde $11^{6)}(1.15 \mathrm{~g}, 2.70 \mathrm{mmol})$ in $\mathrm{CH}_{2} \mathrm{Cl}_{2}(8 \mathrm{ml})$ and pyridine $(1.5 \mathrm{ml})$ was added dropwise, and the reaction mixture was stirred for $30 \mathrm{~min}$ at room temperature. Hexane was added, and insoluble material was removed by decantation. The insoluble material was dissolved in $\mathrm{CH}_{2} \mathrm{Cl}_{2}$ and hexane was added to the solution. The insoluble material wąs removed similarly, and the combined hexane $-\mathrm{CH}_{2} \mathrm{Cl}_{2}$ solution was concentrated under a vacuum. The residue was applied to a silica gel column. Elution with hexane-ethyl acetate $(15: 1)$ gave the dibromide $12(1.24 \mathrm{~g}$, $2.13 \mathrm{mmol}, 79 \%), \mathrm{mp} 139-140^{\circ} \mathrm{C}$ (from acetone). ${ }^{1} \mathrm{H}-\mathrm{NMR} \delta: 0.69\left(3 \mathrm{H}, \mathrm{s}, 18-\mathrm{CH}_{3}\right), 0.95\left(3 \mathrm{H}, \mathrm{d}, J=6 \mathrm{~Hz}, 21-\mathrm{CH}_{3}\right)$, $1.02\left(3 \mathrm{H}, \mathrm{s}, 19-\mathrm{CH}_{3}\right), 3.2-4.2\left(3 \mathrm{H}, \mathrm{m}, 3-\mathrm{H}, 6^{\prime}-\mathrm{H}\right.$ of THP), $4.67\left(1 \mathrm{H}, \mathrm{m}, 2^{\prime}-\mathrm{H}\right.$ of THP), 5.32 (1H, m, 6-H), 6.39 (1H, t, $J=8 \mathrm{~Hz}, 23-\mathrm{H}$ ). Anal. Calcd for $\mathrm{C}_{29} \mathrm{H}_{44} \mathrm{Br}_{2} \mathrm{O}_{2}: \mathrm{C}, 59.57 ; \mathrm{H}, 7.59$. Found: $\mathrm{C}, 59.48 ; \mathrm{H}, 7.46$.

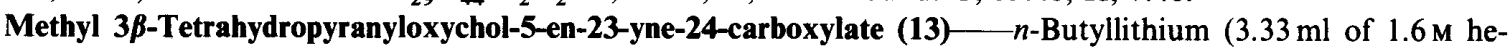
xane solution, $5.33 \mathrm{mmol}$ ) was added to a solution of the dibromide $12(1.24 \mathrm{~g}, 2.13 \mathrm{mmol})$ in $\mathrm{THF}(12 \mathrm{ml})$ at $-78^{\circ} \mathrm{C}$, and the mixture was stirred for $30 \mathrm{~min}$. Then, methyl chloroformate $(0.49 \mathrm{ml}, 6.39 \mathrm{mmol})$ was added dropwise to the mixture and the reaction mixture was stirred for $30 \mathrm{~min}$ at $-78^{\circ} \mathrm{C}$. The usual work-up (ether) afforded a crude product, which was chromatographed on silica gel. Elution with hexane-ethyl acetate $(10: 1)$ gave the methyl ester 13 $\left(791 \mathrm{mg}, 1.64 \mathrm{mmol}, 77^{\circ}\right)$ as an oil. ${ }^{1} \mathrm{H}-\mathrm{NMR} \delta: 0.68\left(3 \mathrm{H}, \mathrm{s}, 18-\mathrm{CH}_{3}\right), 1.01\left(3 \mathrm{H}, \mathrm{s}, 19-\mathrm{CH}_{3}\right), 1.08(3 \mathrm{H}, \mathrm{d}, J=6 \mathrm{~Hz}, 21-$ $\left.\mathrm{CH}_{3}\right), 3.2-4.2\left(3 \mathrm{H}, \mathrm{m}, 3-\mathrm{H}, 6^{\prime}-\mathrm{H}\right.$ of THP), $3.77\left(3 \mathrm{H}, \mathrm{s}, \mathrm{CO}_{2} \mathrm{CH}_{3}\right), 4.70\left(1 \mathrm{H}, \mathrm{m}, 2^{\prime}-\mathrm{H}\right.$ of THP), $5.33(1 \mathrm{H}, \mathrm{m}, 6-\mathrm{H}) . \mathrm{MS}$ $m / z: 482\left(\mathrm{M}^{+}\right),\left(\mathrm{M}-\mathrm{CH}_{3} \mathrm{O}\right)$.

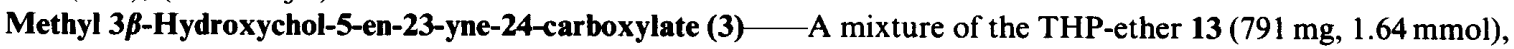
THF $(5 \mathrm{ml})$, methanol $(5 \mathrm{ml})$ and several drops of $2 \mathrm{~N} \mathrm{HCl}$ was stirred at room temperature for $2 \mathrm{~h}$. The usual work-up (ether) gave the alcohol $3(601 \mathrm{mg}, 1.51 \mathrm{mmol}, 92 \%), \mathrm{mp} 151-153^{\circ} \mathrm{C}$ (from hexane) ${ }^{1} \mathrm{H}-\mathrm{NMR}(100 \mathrm{MHz}) \delta: 0.72$ $\left(3 \mathrm{H}, \mathrm{s}, 18-\mathrm{CH}_{3}\right), 1.01\left(3 \mathrm{H}, \mathrm{s}, 19-\mathrm{CH}_{3}\right), 1.10\left(3 \mathrm{H}, \mathrm{d}, \mathrm{J}=6 \mathrm{~Hz}, 21-\mathrm{CH}_{3}\right), 3.60(1 \mathrm{H}, \mathrm{m}, 3-\mathrm{H}), 3.78\left(3 \mathrm{H}, \mathrm{s}, \mathrm{CO}_{2} \mathrm{CH}_{3}\right), 5.35$ $(1 \mathrm{H}, \mathrm{m}, 6-\mathrm{H})$. Anal. Calcd for $\mathrm{C}_{26} \mathrm{H}_{38} \mathrm{O}_{3}: \mathrm{C}, 78.35 ; \mathrm{H}, 9.61$. Found: C, 77.77; H, 9.47.

3及-Hydroxychol-5-en-23-yne-24-carboxylic Acid (14)_A mixture of the methyl ester $3(600 \mathrm{mg}, 1.51 \mathrm{mmol})$ in 1,2-dimethoxyethane $(10 \mathrm{ml})$ and $\mathrm{LiOH} \cdot \mathrm{H}_{2} \mathrm{O}(1.2 \mathrm{~g})$ in $\mathrm{H}_{2} \mathrm{O}(12 \mathrm{ml})$ was stirred at room temperature for $2 \mathrm{~h}$. The mixture was acidified by addition of $2 \mathrm{~N} \mathrm{HCl}$ and extracted twice with ethyl acetate. The combined organic layer was 
washed with brine, dried over $\mathrm{MgSO}_{4}$ and concentrated. The residue was crystallized from methanol to give the hydroxy acid $14(546 \mathrm{mg}, 1.42 \mathrm{mmol}, 94 \%), \mathrm{mp} 221-223^{\circ} \mathrm{C}$. UV $\lambda_{\max }^{\mathrm{E}+\mathrm{OH}} \mathrm{nm}(\log \varepsilon): 218(2.8) . \mathrm{MS} m / z: 340\left(\mathrm{M}-\mathrm{CO}_{2}\right)$. The ${ }^{1} \mathrm{H}$-NMR spectrum was recorded for the methyl ester of 14 , obtained by treatment with diazomethane, and was identical with that of 3.

Methyl 23-Hydroxy-3 $\beta$-tetrahydropyranyloxychol-5-en-24-oate (15) $-n$-Butyllithium $(17.7 \mathrm{ml}$ of $1.6 \mathrm{M}$ hexane solution, $28.3 \mathrm{mmol}$ ) was added dropwise to a solution of diisopropylamine $(3.96 \mathrm{ml}, 28.3 \mathrm{mmol})$ in THF (50 ml) at $-78^{\circ} \mathrm{C}$. The solution was stirred at $-78^{\circ} \mathrm{C}$ for $10 \mathrm{~min}$, at room temperature for $10 \mathrm{~min}$ and finally at $-78^{\circ} \mathrm{C}$ for $20 \mathrm{~min}$. A solution of $3 \beta$-tetrahydropyranyloxycholenic acid methyl ester $(3.56 \mathrm{~g}, 7.55 \mathrm{mmol})$ in THF (13 ml) was added dropwise to the solution of lithium diisopropylamide at $-78^{\circ} \mathrm{C}$, and the mixture was stirred for $1 \mathrm{~h}$. Then, oxygen gas was bubbled into the mixture for $30 \mathrm{~min}$ at $-78^{\circ} \mathrm{C}$. Triethyl phosphite $(2.6 \mathrm{ml}, 15 \mathrm{mmol})$ was added, and the whole was stirred for $15 \mathrm{~min}$. Next, aq. $\mathrm{NH}_{4} \mathrm{Cl}$ was added, and the usual work-up (ether) gave a crude product which was chromatographed on silica gel. Elution with hexane-ethyl acetate $(10: 1)$ afforded $15(2.03 \mathrm{~g}, 4.15 \mathrm{mmol}$, $55 \%$ ) as an amorphous solid. ${ }^{1} \mathrm{H}-\mathrm{NMR}(200 \mathrm{MHz}) \delta$ : 0.68 and 0.71 (each $\left.1.5 \mathrm{H}, \mathrm{s}, 18-\mathrm{CH}_{3}\right), 1.00\left(3 \mathrm{H}, \mathrm{s}, 19-\mathrm{CH}_{3}\right), 1.03$ $\left(3 \mathrm{H}, \mathrm{d}, J=5.4 \mathrm{~Hz}, 21-\mathrm{CH}_{3}\right), 2.68(1 \mathrm{H}, \mathrm{dd}, J=6,18 \mathrm{~Hz}, 23-\mathrm{H}), 3.4-4.0\left(3 \mathrm{H}, \mathrm{m}, 3-\mathrm{H}, 6^{\prime}-\mathrm{H}\right.$ of THP), $3.78(3 \mathrm{H}, \mathrm{s}$, $\left.\mathrm{CO}_{2} \mathrm{CH}_{3}\right), 4.71\left(1 \mathrm{H}, \mathrm{m}, 2^{\prime}-\mathrm{H}\right.$ of THP), $5.35(1 \mathrm{H}, \mathrm{m}, 6-\mathrm{H}) . \mathrm{MS} m / z: 404(\mathrm{M}-\mathrm{THP}+\mathrm{H})$.

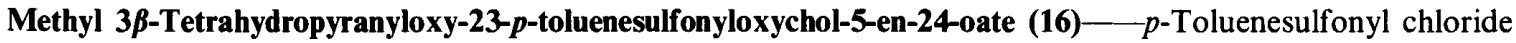
$(1.11 \mathrm{~g}, 5.85 \mathrm{mmol})$ was added to a solution of the alcohol $15(948 \mathrm{mg}, 1.95 \mathrm{mmol})$ in pyridine $(10 \mathrm{ml})$ at $0^{\circ} \mathrm{C}$, and the mixture was stirred overnight. After addition of ice, the mixture was stirred for 20 min, then extracted twice with ethyl acetate. The combined organic layer was washed with $4 \mathrm{~N} \mathrm{HCl}, \mathrm{NaHCO}_{3}$ and brine, and dried over $\mathrm{MgSO}_{4}$. Evaporation of the solvent gave a crude product, which was chromatographed on silica gel. Elution with hexane-ethyl acetate $(7: 1)$ afforded the tosylate $16(774 \mathrm{mg}, 1.21 \mathrm{mmol}, 62 \%)$ as an amorphous solid. ${ }^{1} \mathrm{H}-\mathrm{NMR}$ $(200 \mathrm{MHz}) \delta: 0.57$ and $0.58\left(\right.$ each $\left.1.5 \mathrm{H}, \mathrm{s}, 18-\mathrm{CH}_{3}\right), 0.96\left(3 \mathrm{H}, \mathrm{d}, J=7 \mathrm{~Hz}, 21-\mathrm{CH}_{3}\right), 1.00\left(3 \mathrm{H}, \mathrm{s}, 19-\mathrm{CH}_{3}\right), 2.44(3 \mathrm{H}, \mathrm{s}$, $\left.\mathrm{CH}_{3}-\mathrm{Ph}\right), 3.4-4.0\left(3 \mathrm{H}, \mathrm{m}, 3-\mathrm{H}, 6^{\prime}-\mathrm{H}\right.$ of THP), 3.65 and 3.66 (each $\left.1.5 \mathrm{H}, \mathrm{s}, \mathrm{CO}_{2} \mathrm{CH}_{3}\right), 4.72\left(1 \mathrm{H}, \mathrm{m}, 2^{\prime}-\mathrm{H}\right.$ of THP), $4.85(1 \mathrm{H}, \mathrm{m}, 23-\mathrm{H}), 5.35(1 \mathrm{H}, \mathrm{m}, 6-\mathrm{H}), 7.36(2 \mathrm{H}, \mathrm{d}, J=7 \mathrm{~Hz}, \mathrm{Ph}), 7.82(2 \mathrm{H}, \mathrm{d}, J=7 \mathrm{~Hz}, \mathrm{Ph}) . \mathrm{MS} m / z: 386$ $(\mathrm{M}-\mathrm{THP}-\mathrm{TsOH}+\mathrm{H})$

Methyl 23-Bromo-3 $\beta$-tetrahydropyranyloxychol-5-en-24-oate (17) $-\mathrm{LiBr}(315 \mathrm{mg}, 3.62 \mathrm{mmol})$ was added to a solution of the tosylate $16(774 \mathrm{mg}, 1.21 \mathrm{mmol})$ in acetone $(15 \mathrm{ml})$, and the mixture was refluxed for $6 \mathrm{~h}$, then concentrated under a vacuum and diluted with ether. The solution was washed with $2 \mathrm{~N} \mathrm{HCl}, \mathrm{NaHCO}_{3}$ and brine, and dried over $\mathrm{MgSO}_{4}$. The solvent was evaporated off and the residue was chromatographed on silica gel. Elution with hexane-ethyl acetate $(20: 1)$ gave the bromide $17(595 \mathrm{mg}, 1.08 \mathrm{mmol}, 89 \%), \mathrm{mp} 118-140^{\circ} \mathrm{C}$ (from $\left.\mathrm{MeOH}\right) .{ }^{1} \mathrm{H}-$ $\operatorname{NMR}(200 \mathrm{MHz}) \delta: 0.65$ and $0.72\left(\right.$ each $\left.1.5 \mathrm{H}, \mathrm{s}, 18-\mathrm{CH}_{3}\right), 0.94$ and $0.96\left(\right.$ each $\left.1.5 \mathrm{H}, \mathrm{d}, J=6 \mathrm{~Hz}, 21-\mathrm{CH}_{3}\right), 1.01(3 \mathrm{H}, \mathrm{s}$, 19- $\left.\mathrm{CH}_{3}\right), 3.4-4.0\left(3 \mathrm{H}, \mathrm{m}, 3-\mathrm{H}, 6^{\prime}-\mathrm{H}\right.$ of THP), $3.79\left(3 \mathrm{H}, \mathrm{s}, \mathrm{CO}_{2} \mathrm{CH}_{3}\right), 4.30$ and 4.33 (each $0.5 \mathrm{H}, \mathrm{dd}, J=3.5,11.4 \mathrm{~Hz}$, and $4.4,11.2 \mathrm{~Hz}$, respectively, $23-\mathrm{H}), 4.73\left(1 \mathrm{H}, \mathrm{m}, 2^{\prime}-\mathrm{H}\right.$ of THP), $5.37(1 \mathrm{H}, \mathrm{m}, 6-\mathrm{H})$. Anal. Calcd for $\mathrm{C}_{30} \mathrm{H}_{47} \mathrm{BrO}_{4}: \mathrm{C}^{\prime}$ 65.32; H, 8.59. Found: C, 65.30; H, 8.60.

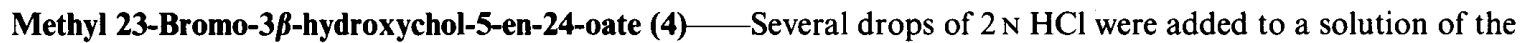
THP-ether $17(595 \mathrm{mg}, 1.08 \mathrm{mmol})$ in THF $(10 \mathrm{ml})-\mathrm{MeOH}(10 \mathrm{ml})$, and the mixture was stirred at room temperature for $2 \mathrm{~h}$. Then, ethyl acetate was added and the usual work-up gave a crude product, which was chromatographed on silica gel. Elution with hexane-ethyl acetate $(3: 1)$ gave the bromide $4(449 \mathrm{mg}, 0.96 \mathrm{mmol}, 89 \%), \mathrm{mp} 119-132^{\circ} \mathrm{C}^{12)}$ (from MeOH). ${ }^{1} \mathrm{H}-\mathrm{NMR}(200 \mathrm{MHz}) \delta: 0.65$ and $0.72\left(\right.$ each $\left.1.5 \mathrm{H}, \mathrm{s}, 18-\mathrm{CH}_{3}\right), 0.94$ and $0.96($ each $1.5 \mathrm{H}, \mathrm{d}, J=6 \mathrm{~Hz}$, $\left.21-\mathrm{CH}_{3}\right), 1.01\left(3 \mathrm{H}, \mathrm{s}, 19-\mathrm{CH}_{3}\right), 3.50(1 \mathrm{H}, \mathrm{m}, 3-\mathrm{H}), 3.77\left(3 \mathrm{H}, \mathrm{s}, \mathrm{CO}_{2} \mathrm{CH}_{3}\right), 4.31$ and 4.34 (each $0.5 \mathrm{H}, \mathrm{dd}, J=11.4$, $3.5 \mathrm{~Hz}$, and $12.0,4.0 \mathrm{~Hz}$, respectively, $23-\mathrm{H}), 5.33(1 \mathrm{H}, \mathrm{m}, 6-\mathrm{H})$. MS $m / z: 466 / 468\left(\mathrm{M}^{+}\right)$. Anal. Calcd for $\mathrm{C}_{25} \mathrm{H}_{39} \mathrm{BrO}_{3}$ : C, 64.23; H, 8.41. Found: C, 64.22; H, 8.44.

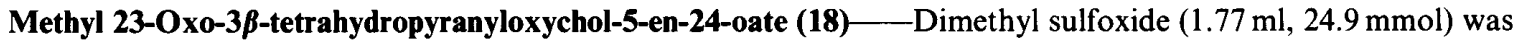
added dropwise to a solution of oxalyl chloride $(1.09 \mathrm{ml}, 12.5 \mathrm{ml})$ in $\mathrm{CH}_{2} \mathrm{Cl}_{2}$ at $-78^{\circ} \mathrm{C}$, and the mixture was stirred for $5 \mathrm{~min}$. A solution of the alcohol $15(2.03 \mathrm{~g}, 4.15 \mathrm{mmol})$ in $\mathrm{CH}_{2} \mathrm{Cl}_{2}(8 \mathrm{ml})$ was then added dropwise at $-78^{\circ} \mathrm{C}$. The whole was stirred for $20 \mathrm{~min}$, then triethylamine $(3.50 \mathrm{ml}, 24.9 \mathrm{mmol})$ was added, and the reaction mixture was warmed gradually to room temperature. The usual work-up (ether) gave a crude product which was chromatographed on silica gel. Elution with hexane-ethyl acetate $(15: 1)$ gave $18(1.92 \mathrm{~g}, 3.94 \mathrm{mmol}, 95 \%)$ as an amorphous solid. ${ }^{1} \mathrm{H}-\mathrm{NMR} \delta: 0.71\left(3 \mathrm{H}, \mathrm{s}, 18-\mathrm{CH}_{3}\right), 0.95\left(3 \mathrm{H}, \mathrm{d}, J=6 \mathrm{~Hz}, 21-\mathrm{CH}_{3}\right), 0.99\left(3 \mathrm{H}, \mathrm{s}, 19-\mathrm{CH}_{3}\right), 2.71\left(2 \mathrm{H}, \mathrm{m}, 22-\mathrm{H}_{2}\right)$, $3.2-4.1\left(3 \mathrm{H}, \mathrm{m}, 3-\mathrm{H}, 6^{\prime}-\mathrm{H}\right.$ of THP), $3.85\left(3 \mathrm{H}, \mathrm{s}, \mathrm{CO}_{2} \mathrm{CH}_{3}\right), 4.70\left(1 \mathrm{H}, \mathrm{m}, 2^{\prime}-\mathrm{H}\right.$ of THP), $5.33(1 \mathrm{H}, \mathrm{m}, 6-\mathrm{H}) . \mathrm{MS}$ $m / z: 402(\mathrm{M}-\mathrm{THP}+\mathrm{H})$.

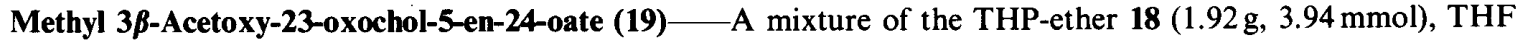
$(7 \mathrm{ml})$, methanol $(7 \mathrm{ml})$ and several drops of $2 \mathrm{~N} \mathrm{HCl}$ was stirred at room temperature for $2 \mathrm{~h}$. The usual work-up (ethyl acetate) and purification by silica gel column chromatography (elution with hexane-ethyl acetate $(5: 2)$ ) gave the $3 \beta$-alcohol $(1.22 \mathrm{~g}, 3.04 \mathrm{mmol}, 77 \%)$, mp 163.5-165 ${ }^{\circ} \mathrm{C}$ (from methanol). ${ }^{1} \mathrm{H}-\mathrm{NMR} \delta: 0.75\left(3 \mathrm{H}, \mathrm{s}, 18-\mathrm{CH}_{3}\right), 1.00$ $\left(3 \mathrm{H}, \mathrm{d}, J=7 \mathrm{~Hz}, 21-\mathrm{CH}_{3}\right), 1.07\left(3 \mathrm{H}, \mathrm{s}, 19-\mathrm{CH}_{3}\right), 2.69\left(2 \mathrm{H}, \mathrm{m}, 22-\mathrm{H}_{2}\right), 3.60(1 \mathrm{H}, \mathrm{m}, 3-\mathrm{H}), 3.86\left(3 \mathrm{H}, \mathrm{s}, \mathrm{CO}_{2} \mathrm{CH}_{3}\right), 5.33$ $(1 \mathrm{H}, \mathrm{m}, 6-\mathrm{H})$. Anal. Calcd for $\mathrm{C}_{25} \mathrm{H}_{38} \mathrm{O}_{4}: \mathrm{C}, 74.59 ; \mathrm{H}, 9.52$. Found: C, 74.34; H, 9.45. Acetyl chloride $(0.21 \mathrm{ml}$, $3.04 \mathrm{mmol})$ was added to a solution of the $3 \beta$-alcohol $(1.22 \mathrm{~g}, 3.04 \mathrm{mmol})$ in pyridine $(15 \mathrm{ml})$ at $0{ }^{\circ} \mathrm{C}$, and the mixture was stirred for $30 \mathrm{~min}$. The usual work-up gave a crude product, which was chromatographed on silica gel. Elution with hexane-ethyl acetate ( $5: 1)$ gave $19\left(933 \mathrm{mg}, 2.10 \mathrm{mmol}, 76 \%\right.$ ), mp 143-145 ${ }^{\circ} \mathrm{C}$ (from hexane). ${ }^{1} \mathrm{H}-\mathrm{NMR} \delta: 0.73$ 
$\left(3 \mathrm{H}, \mathrm{s}, 18-\mathrm{CH}_{3}\right), 0.97\left(3 \mathrm{H}, \mathrm{d}, J=6 \mathrm{~Hz}, 21-\mathrm{CH}_{3}\right), 1.02\left(3 \mathrm{H}, \mathrm{s}, 19-\mathrm{CH}_{3}\right), 2.04(3 \mathrm{H}, \mathrm{s}, 3-\mathrm{OAc}), 2.72\left(2 \mathrm{H}, \mathrm{m}, 22-\mathrm{H}_{2}\right), 3.86$ $\left(3 \mathrm{H}, \mathrm{s}, \mathrm{CO}_{2} \mathrm{CH}_{3}\right), 4.58(1 \mathrm{H}, \mathrm{m}, 3-\mathrm{H}), 5.38(1 \mathrm{H}, \mathrm{m}, 6-\mathrm{H})$. Anal. Calcd for $\mathrm{C}_{27} \mathrm{H}_{40} \mathrm{O}_{5}$ : C, 72.94; H, 9.07. Found: C, 73.09; H, 9.04 .

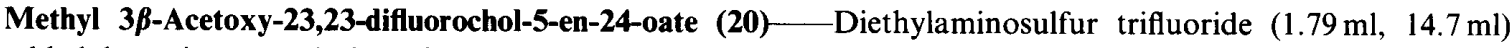
wad added dropwise to a solution of $19(933 \mathrm{mg}, 2.10 \mathrm{mmol})$ in $\mathrm{CH}_{2} \mathrm{Cl}_{2}(10 \mathrm{ml})$ at $0^{\circ} \mathrm{C}$, and the mixture was stirred at room temperature for $16 \mathrm{~h}$. After addition of $5 \% \mathrm{NaHCO}_{3}$, the usual work-up (ether) gave a crude product which was chromatographed on silica gel. Elution with hexane-ethyl acetate $(50: 1)$ gave $20\left(651 \mathrm{mg}, 1.40 \mathrm{mmol}, 67^{\circ}\right), \mathrm{mp}$ $135-136.5^{\circ} \mathrm{C}$ (from hexane). ${ }^{1} \mathrm{H}-\mathrm{NMR} \delta: 0.70\left(3 \mathrm{H}, \mathrm{s}, 18-\mathrm{CH}_{3}\right), 1.02\left(3 \mathrm{H}, \mathrm{s}, 19-\mathrm{CH}_{3}\right), 1.03\left(3 \mathrm{H}, \mathrm{d}, J=7 \mathrm{~Hz}, 21-\mathrm{CH}_{3}\right)$, $2.02(3 \mathrm{H}, \mathrm{s}, 3-\mathrm{OAc}), 3.86\left(3 \mathrm{H}, \mathrm{s}, \mathrm{CO}_{2} \mathrm{CH}_{3}\right), 4.58(1 \mathrm{H}, \mathrm{m}, 3-\mathrm{H}), 5.34(1 \mathrm{H}, \mathrm{m}, 6-\mathrm{H})$. Anal. Calcd for $\mathrm{C}_{27} \mathrm{H}_{40} \mathrm{~F}_{2} \mathrm{O}_{4}: \mathrm{C}_{\text {, }}$ 69.50; H, 8.64. Found: C, 69.67; H, 8.54. MS m/z: 406 (M-AcOH).

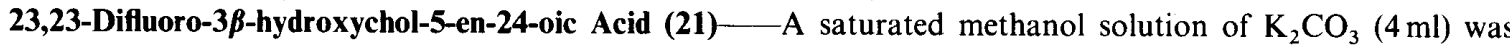
added to a solution of the açetate $20(651 \mathrm{mg}, 1.40 \mathrm{mmol})$ inTHF $(8 \mathrm{ml})$ and methanol $(5 \mathrm{ml})$, and the mixture was stirred at room temperature for $1 \mathrm{~h}$, acidified by addition of $2 \mathrm{~N} \mathrm{HCl}$, and extracted twice with ethyl acetate. The combined organic layer was washed with brine, dried over $\mathrm{MgSO}_{4}$ and concentrated. The residue was crystallized from ethyl acetate to afford $21\left(561 \mathrm{mg}, 1.37 \mathrm{mmol}, 98 \%\right.$ ), $\mathrm{mp} \mathrm{ca} .210^{\circ} \mathrm{C}$ (dec.). MS m/z: $410\left(\mathrm{M}^{+}\right)$.

Methyl 23,23-Difluoro-3 $\beta$-hydroxychol-5-en-24-oate (5)—-The acid 21 was esterified with diazomethane as described for 9 . Purification of the crude product on a silica gel column (eluted with hexane-ethyl acetate $(2: 1)$ ) afforded the methyl ester $5(19 \mathrm{mg}, 91 \%), \mathrm{mp} 154-156.5^{\circ} \mathrm{C}$ (from ethyl acetate). ${ }^{1} \mathrm{H}-\mathrm{NMR}(100 \mathrm{MHz}) \delta: 0.72(3 \mathrm{H}, \mathrm{s}$, $\left.18-\mathrm{CH}_{3}\right), 1.02\left(3 \mathrm{H}, \mathrm{s}, 19-\mathrm{CH}_{3}\right), 1.04\left(3 \mathrm{H}, \mathrm{d}, \mathrm{J}=6 \mathrm{~Hz}, 21-\mathrm{CH}_{3}\right), 3.60(1 \mathrm{H}, \mathrm{m}, 3-\mathrm{H}), 3.88\left(3 \mathrm{H}, \mathrm{s}, \mathrm{CO}_{2} \mathrm{CH}_{3}\right), 5.36(1 \mathrm{H}, \mathrm{m}$, 6-H). MS $m / z: 424\left(\mathrm{M}^{+}\right)$.

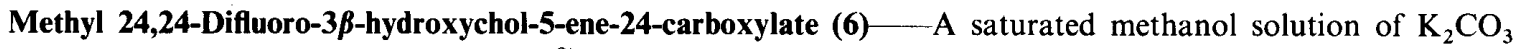
$(1 \mathrm{ml})$ was added to a solution of the acetate ${ }^{9)} 22(100 \mathrm{mg}, 0.21 \mathrm{mmol})$ in THF $(2 \mathrm{ml})$ and methanol $(1 \mathrm{ml})$, and the mixture was stirred at room temperature for $1 \mathrm{~h}$, acidified by addition of $2 \mathrm{~N} \mathrm{HCl}$, and extracted twice with ethyl acetate. The combined organic layer was washed with brine, dried over $\mathrm{MgSO}_{4}$ and evaporated to dryness. The residue was treated with a large excess of diazomethane at $0^{\circ} \mathrm{C}$ to give the hydroxy methyl ester $6(81 \mathrm{mg}, 0.19 \mathrm{mmol}$, $90 \%$ ) mp 128-132 ${ }^{\circ} \mathrm{C}$ (from methanol). ${ }^{1} \mathrm{H}-\mathrm{NMR}(200 \mathrm{MHz}) \delta: 0.68\left(3 \mathrm{H}, \mathrm{s}, 18-\mathrm{CH}_{3}\right), 0.94\left(3 \mathrm{H}, \mathrm{d}, J=6 \mathrm{~Hz}, 21-\mathrm{CH}_{3}\right)$, $1.00\left(3 \mathrm{H}, \mathrm{s}, 19-\mathrm{CH}_{3}\right), 3.54(1 \mathrm{H}, \mathrm{m}, 3-\mathrm{H}), 3.87\left(3 \mathrm{H}, \mathrm{s}, \mathrm{CO}_{2} \mathrm{CH}_{3}\right), 5.35(1 \mathrm{H}, \mathrm{m}, 6-\mathrm{H})$. Anal. Calcd for $\mathrm{C}_{26} \mathrm{H}_{40} \mathrm{~F}_{2} \mathrm{O}_{3}: \mathrm{C}_{\text {, }}$ 71.20; H, 9.19. Found: C, 71.34; H, 9.15.

Incubation-Mycobacterium sp. NRRL B-3805 was grown for $1 \mathrm{~d}$ in liquid medium ${ }^{10)}(20 \mathrm{ml})$ containing nutrient broth $(160 \mathrm{mg})$, yeast extract $(20 \mathrm{mg})$ and cholesterol $(1.0 \mathrm{mg})$, and then a solution of cholesterol $(10 \mathrm{mg})$ and the test inhibitor (a variable amount) in dimethylformamide $(0.7 \mathrm{ml})$ was added. After incubation for another $4 \mathrm{~d}$, the mixture was extracted with ethyl acetate and the conversion yield into AD was analyzed, after $\mathrm{CH}_{2} \mathrm{~N}_{2}$ treatment, by GLC.

Acknowledgement This work was supported in part by a Grant-in-Aid for Scientific Research (No. 59870068) from the Ministry of Education, Science and Culture, Japan.

\section{References and Notes}

1) C. J. Sih, K. C. Wang, and H. H. Tai, Biochemistry, 7, 796 (1986); C. J. Sih, H. H. Tai, Y. Y. Tsong, S. S. Lee, and R. G. Coombe, ibid., 7, 808 (1968); Y. Fujimoto, C.-S. Chen, Z. Szeleczky, D. DiTullio, and C. J. Sih, J. Am. Chem. Soc., 104, 4718 (1982); Y. Fujimoto, C.-S. Chen, A. S. Gopalan, and C. J. Sih, ibid., 104, 4720 (1982).

2) K. Arima, Roussel Prize Lecture, 1980, 15; C. J. Sih, ibid., 1980, 35; M. G. Wovcha, F. J. Antosz, J. C. Knight, L. A. Kaminek, and T. R. Pyke, Biochem. Biophys. Acta, 531, 308 (1978).

3) E.g. N. Koizumi, M. Ishiguro, M. Yasuda, and N. Ikekawa, J. Chem. Soc., Perkin Trans. I, 1983, 1401.

4) W. G. Salmond, M. C. Sobala, and K. D. Maisto, Tetrahedron Lett., 1977, 1237.

5) M. L. Raggio and D. S. Watt, J. Org. Chem., 41, 1873 (1976).

6) Compound 11 was obtained from the corresponding $3 \beta$-ol; S. Sato, A. Akaiwa, Y. Fujimoto, M. Ishiguro, and N. Ikekawa, Chem. Pharm. Bull., 29, 406 (1981).

7) E. J. Corey and P. L. Fucks, Tetrahedron Lett., 1972, 3769.

8) M. A. Gilhooly, D. S. Morris, and D. H. Williams, J. Chem. Soc., Perkin Trans. 1, 1982, 2111.

9) Preparation of 22 will be reported elsewhere.

10) W. J. Marheck, S. Kraychy, and R. D. Muir, Appl. Microbiol., 23, 72 (1972).

11) $3 \beta$-Hydroxycholenic acid methyl ester showed some inhibitory activity, but was less active than 3 .

12) This is due to the presence of a mixture of C-23 epimers. Stereochemically homogeneous isomer (23S)- or (23R)4 could be obtained since the epimers of the tosylate 16 are separable on thin-layer chromatography. 